\title{
Relative growth in the fiddler crab Uca uruguayensis Nobili, 1901 (Brachyura, Ocypodidae) from Garças River mangrove, Guaratuba Bay, southern Brazil
}

Salise Brandt Martins and Setuko Masunari

(SBM, SM) Department of Zoology, Institute of Biological Sciences, Federal University of Paraná. Centro Politécnico, Jardim das Américas, Caixa Postal 19020, 81531-980, Curitiba, Paraná, Brazil. E-mails: (SBM) salisebrandt@yahoo.com.br; (SM) setmas@ufpr.br

\begin{abstract}
A study on the relative growth was carried out in a population of the fiddler crab Uca uruguayensis from the mangrove of Garças River, Guaratuba Bay, Paraná State, southern Brazil. The dimensions analyzed were the length of the major chela (LMC) of males and width of the abdomen (AW) of females, because they are related to reproductive activities of waving (males) and egg incubation (females). The cheliped handedness in males was also analyzed. The LMC was measured in 480 males, the AW in 566 females, and all crabs had the carapace width $(\mathrm{CW})$ measured that was considered as the reference dimension for both sexes. The inflection point in the graphs between each the dimensions and CW was calculated with the aid of the software REGRANS. The CW ranged from 2.33 to $8.33 \mathrm{~mm}$ in males and from 1.65 to $7.79 \mathrm{~mm}$ in females. The relationship between CW and LMC showed an inflection point at $4.14 \mathrm{~mm}$ $\mathrm{CW}$ among males, and between $\mathrm{CW}$ and $\mathrm{AW}$ at $3.52 \mathrm{~mm} \mathrm{CW}$ among females. The allometric growth was positive for both dimensions throughout the entire ontogeny of both sexes, before and after the puberty. The equations describing the relationship between CW and LMC in males were: $\operatorname{logLMC}=-0.695960$ $+1.72 \cdot \log \mathrm{CW}$ for juveniles and $\log \mathrm{LMC}=-1.212513+2.5 \cdot \log \mathrm{CW}$ for adults. In females, the equations were $\log \mathrm{AW}=-0.519071+1.02 \cdot \log \mathrm{CW}$ and $\log \mathrm{AW}$ $=-0.902874+1.73 . \log \mathrm{CW}$, respectively for juveniles and adults. The population of $U$. uruguayensis from Guaratuba Bay is composed of the smallest crabs, and it also attains morphological sexual maturity at smallest CW. The frequency of occurrence of right and left handed males was statistically the same (1:1) as in most population of fiddler crabs.
\end{abstract}

Key words: Fiddler crab, major chela length, REGRANS, width of the abdomen

\section{INTRODUCTION}

Some somatic dimensions of an animal can grow at different rates than others which results in changes of the body proportion during its increase in size. This phenomenon is called relative or allometric growth (Hartnoll, 1978), and can be used as a tool to deduce the size at which a species attains its morphological sexual maturity. Crustaceans are particularly appropriate for this study due to their hard exoskeleton that allows precise measurements, and to abrupt changes in the proportions of the body dimensions by the pubertal moulting (Hartnoll, 1978). The two dimensions that are 
usually analyzed in research among decapod brachyurans are the major chela length of males and the width of females abdomen, because they are secondary sexual characters closely associated with the reproductive activities of each sex and constitute elements of sexual dimorphism in adulthood (Hartnoll, 1982).

Crabs of the genus $U_{c a}$ Leach, 1814 are widely studied on relative growth due to their apparent contrasting sexual dimorphism: the adult male's giant cheliped readily allows distinguishing it from female. For this reason, these animals were object of morphometric studies in several countries: Uca pugilator Bosc, 1802 in Massachusetts, USA (Miller, 1973), Uca subcylindrica Stimpson, 1859 in Texas, USA (Thurman II, 1984), Uca pugnax Smith, 1870 in New York, USA (Rosenberg, 1997), Uca lactea Haan, 1835 from various regions of Japan (Yamaguchi, 1977) and Uca arcuata Haan, 1833 from Kyushu, Japan (Yamaguchi, 2001; Yamaguchi and Henmi, 2001).

A total of ten species of $U_{c a}$ are known from Brazil, among which, seven had their relative growth studied: Uca rapax Smith, 1870 from Rio de Janeiro State (Castiglioni et al., 2006; Costa and Soares-Gomes, 2008) and from São Paulo State (Castiglioni and Negreiros-Fransozo, 2004); Uca thayeri Rathbun, 1900 (Negreiros-Fransozo et al., 2003); Uca burgersi Holthuis, 1967 (Benetti and Negreiros-Fransozo, 2004); Uca leptodactyla Rathbun, 1898 from São Paulo State (Cardoso and Negreiros-Fransozo, 2004) and from Santa Catarina State (Masunari and Swiech-Ayoub, 2003); Uca mordax Smith, 1870 (Masunari and Dissenha, 2005); Uca maracoani Latreille, 1802-1803 (Masunari et al., 2005) from Paraná State; and Uca uruguayensis Nobili, 1901 from São Paulo State and from Samborombón, Argentina (Hirose et al., 2013).

The present work aims to describe the relative growth of the major chela length of males and of the abdomen of females of $U c a$ uruguayensis from a southern mangrove of Brazil. This species is distributed along the
Western Atlantic coast, from Rio de Janeiro State (Brazil) to the mouth of the Quequén River in the province of Buenos Aires (Argentina) (Melo, 1996; Boschi, 2000).

\section{Material And Methods}

The study area is inserted into Boguaçu State Park, inside the Guaratuba Bay, Paraná State coast, southern Brazil. This bay has about 40 $\mathrm{Km}^{2}$ area and has a connection with the sea through a narrow channel about 500 m wide. The samplings were conducted at Garças River mangrove $\left(25^{\circ} 53^{\prime} \mathrm{S} / 48^{\circ} 38^{\prime} \mathrm{W}\right)$ located in the southern area of the bay.

The collections were made on the sunny riverbanks adjacent to mangrove forest where Uca uruguayensis usually occurs. Eight samples of $0.50 \times 0.50 \mathrm{~cm}$ were randomly monthly taken during spring tides, from April 2011 to March 2012. All open burrows inside the sample square were inspected and the crabs were manually collected with the aid of a small garden shovel. The animals were transported to the laboratory inside a thermal box with ice where they were fixed in formalin and preserved in alcohol $75 \%$. The low-temperature thermal box had the purpose to avoid the loss of chelipeds in crabs under stress condition. In the laboratory, crabs were sexed and morphometric measurements were taken under a digital microscope (Dino-Lite Pro AM-413T). The width of the carapace (CW) was measured in both sexes. The length of the major chela (LMC), from the proximal border of propod to the distal end of the finger, was measured in males. The maximum width of the abdomen (AW) at the fourth abdominal segment was measured in females. These dimensions (LMC and AW) were chosen because they are related to the reproduction of each sex and constitute elements of sexual dimorphism in adulthood (Hartnoll, 1982). In addition, the handedness of males was analyzed. It was called righthanded the crab with the largest cheliped on the right side and left-handed that of the left side, following Yamaguchi (1977). 
The power equation $Y=a X^{b}$ was used, where ' $a$ ' is the intersection of ' $y$ ', and ' $b$ ' is the constant allometric growth. The equation was linearized $(\log y=\log a+b \cdot \log x)$, where the $\mathrm{CW}$ was considered the independent variable $(\mathrm{x})$, since it is the most representative of overall size of the animal (Hartnoll, 1982). The remaining dimensions (LMC and AW) were considered as dependent variables (y). The inflection point in the dispersion graph between the empirical dots was calculated with the aid of the software REGRANS (Pezzuto, 1993). This inflection point indicates the beginning of morphological sexual maturity for decapod crustaceans (Hartnoll, 1974; 1978). The allometric coefficient (b) of the equation that expresses the relationship between the analyzed dimensions, was tested with $\mathrm{t}$-Student to verify if the allometric growth was positive $(b>1)$, negative $(b<1)$ or isometric $(b=1)$. The similarity between the slopes and intercepts of straight lines representing each phase of development in the dispersion graphs was tested through covariance analysis (ANCOVA) with 95\% confidence (Zar, 1999). In the study of the handedness of males, the Chi-square test was used with $95 \%$ confidence.

\section{Results}

A total of 1,046 sexually differentiated crabs were measured: 480 males and 566 females. Male CW ranged from 2.33 to $8.33 \mathrm{~mm}$, while females' ranged from 1.65 to $7.79 \mathrm{~mm}$. Male LMC ranged from 0.87 to $12.06 \mathrm{~mm}$ and female AW from 0.44 to $4.30 \mathrm{~mm}$.

In the dispersion graph of the empirical dots between CW and LMC of males there was an inflection point at $4.14 \mathrm{~mm} \mathrm{CW}$ that discriminated the subset of juveniles at left with 137 individuals, and that of adults at right with 343 individuals (Fig. 1). During the ontogenetic development of males, the LMC had a positive allometric growth $(b>1)$, both in the juvenile phase (test of significance of declivity, $\mathrm{TSD}=16.29$ ) as in the adulthood $(\mathrm{TSD}=60.86)$. This allometry indicated that the LMC grew at a higher rate than the CW during all the life of males (Fig. 1). The expressions of the straight lines that determined the relationship between CW and juvenile and adult males LMC were, respectively, logLMC $=-0.695960+1.72 \cdot \log \mathrm{CW}$ and $\operatorname{logLMC}=$ $-1.212513+2.5 \cdot \log \mathrm{CW}$ (Tab. 1$)$.

During the ontogeny of females, the AW also grew faster than $\mathrm{CW}$, i.e., it had a positive allometric growth $(b>1)$, both in the juvenile

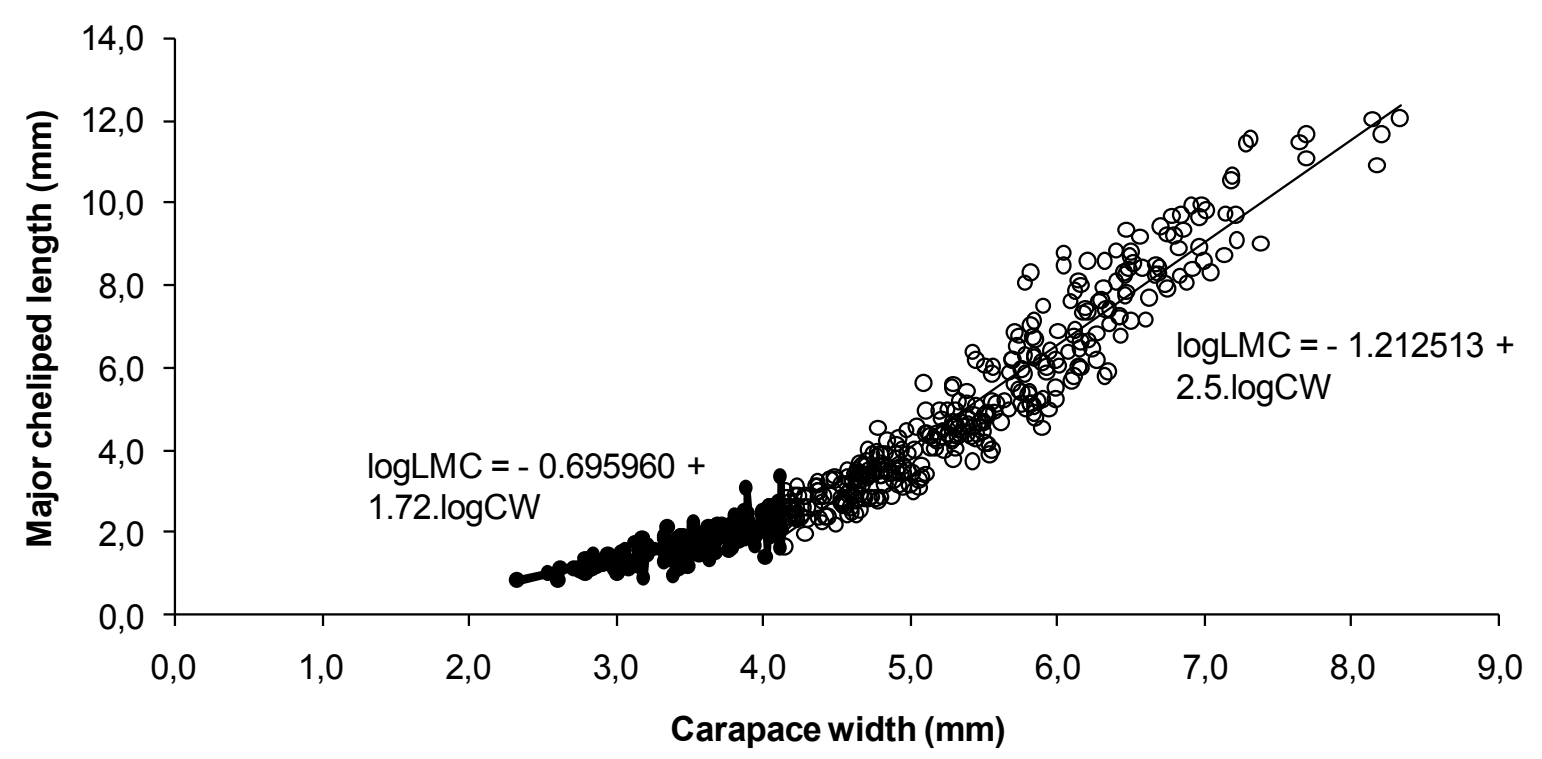

Figure 1. Uca uruguayensis. Dispersion graph of the empirical dots between the width of the carapace (CW) and the length of the major chela (LMC) in males. The inflection point is observed at $4.14 \mathrm{~mm} \mathrm{CW}$. The black dots on the left correspond to sexually immature crabs and the right ones to adults (open circles). 
Table 1. Uca uruguayensis. Statistics of linear relationships between the major chela length (LMC) and the carapace width (CW) of males, and between the abdomen width (AW) of females. (X) inflection point, $(\mathrm{N})$ sample size, $(\mathrm{r})$ correlation coefficient, $\left(\mathrm{r}^{2}\right)$ coefficient of determination, (a) intersection and (b) declivity.

\begin{tabular}{lccccccc}
\hline Variables & Categories & $\mathbf{N}$ & $\mathbf{r}$ & $\mathbf{r}^{2}$ & $\mathbf{a}$ & $\mathbf{b}$ (I.C.95\%) & Allometry \\
\hline Males & & & & & & & \\
$(\mathrm{CW}$ x LMC; & Juvenile & 137 & 0.814251 & 0.663004 & -0.695960 & 1.722467 & + \\
$\mathrm{X}=4.14)$ & Adult & 343 & 0.956921 & 0.915698 & -1.212513 & 2.583311 & + \\
Females & & & & & & & + \\
$(\mathrm{CW}$ x AW; & Juvenile & 151 & 0.875335 & 0.766211 & -0.519071 & 1.022844 & + \\
$\mathrm{X}=3.52)$ & Adult & 415 & 0.950105 & 0.902700 & -0.902874 & 1.736035 & + \\
\hline
\end{tabular}

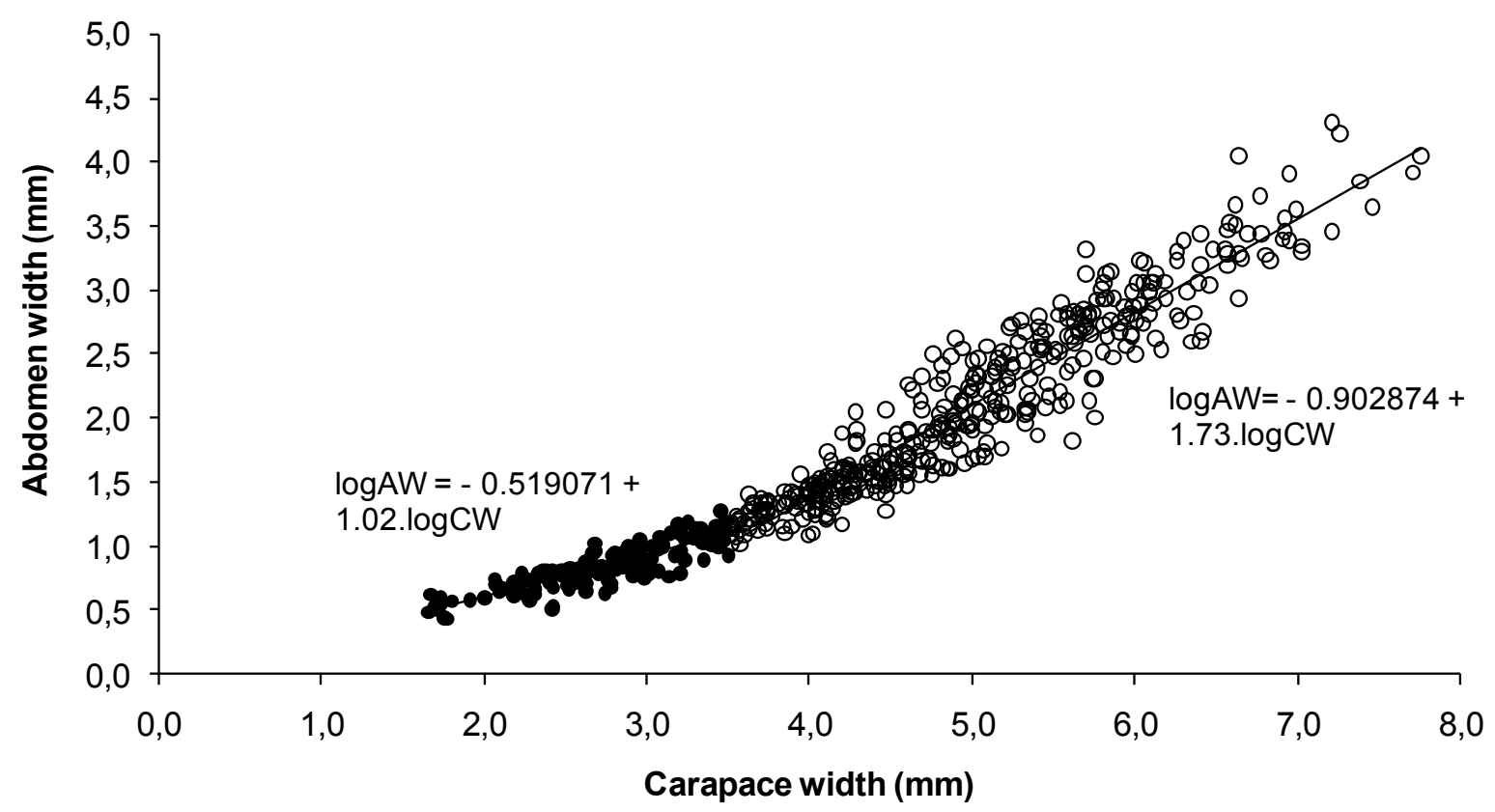

Figure 2. Uca uruguayensis. Dispersion graph of the empirical dots between the width of the carapace (CW) and the abdomen width (AW) of the females. The inflection is observed at $3.52 \mathrm{~mm} \mathrm{CW}$. The black dots on the left correspond to sexually immature crabs and the right ones to adults (open circles).

phase $(T S D=22.09)$ and in the adulthood $(T S D=61.90)$. The dispersion graph of the empirical dots between CW and AW showed an inflection point at $3.52 \mathrm{~mm} \mathrm{CW}$ that discriminated a subset of 151 juvenile individuals at left and another of 145 adults at right (Fig. 2). The expression that determined the relationship between $\mathrm{CW}$ and AW of juvenile females was: $\log A W=-0.519071+$ 1.02. $\log \mathrm{CW}$, while that of adults was $\log A \mathrm{~W}$ $=-0.902874+1.73 \cdot \log \mathrm{CW}$ (Tab. 1). The smallest ovigerous female measured $5.05 \mathrm{~mm}$ $\mathrm{CW}$. The inflection points were slightly below half the maximum values of $\mathrm{CW}$ for both sexes.

The heterochely of males started from 2.61 mm CW, when the LMC measured 0.87 $\mathrm{mm}$; the latter dimension ranged from 0.87 to
$12.06 \mathrm{~mm}$. Among 516 males with undamaged chelipeds, 258 were right-handed and 258 lefthanded, and therefore no statistical difference was found.

\section{DisCUSSION}

The small size of the crabs composing the population of $U$ ca uruguayensis from Guaratuba Bay deserves special attention. While the male's maximum CW of the populations from Ubatuba, SP (Brazil) and from Samborobón (Argentina) measured $11.60 \mathrm{~mm}$ and 14.10 mm, respectively (Hirose et al., 2013), that of Guaratuba Bay was $8.33 \mathrm{~mm}$. This difference is still more striking when compared with the population from Maldonado, Uruguay $(=16.0 \mathrm{~mm} \mathrm{CW})$, which is almost twice 
the size determined for Guaratuba's males (Nobili, 1901). The dimensions for females are proportional for each population. The CW values in which crabs attain sexual maturity (inflexion points) were also proportional to the average size of the crabs in each population: again the population of Guaratuba Bay becomes mature at smaller sizes than other populations (Tab. 2). Certainly, the highly contrasting abiotic condition prevalent in each area is the main reason for this size variability, which is not surprising considering the distribution area of the species of ca. $3,170 \mathrm{~km}$ (from Rio de Janeiro State, Brazil to Quequén River, Argentina). In each area, the food availability, type of substratum and abiotical variables are peculiar, resulting in populations with different parameters (Hines, 1989).

The positive allometric growth recorded in both analyzed dimensions during the entire life of $U$. uruguayensis agrees with the prediction of Hartnoll (1982) for brachyuran crabs: slightly positive allometry in the juvenile phase and strongly positive in the adulthood. Therefore, in this species both the LMC and the AW grow faster than the CW throughout its ontogeny, with greater intensity in adulthood. These results seem to be a general rule for Uca species occurring in southeastern and southern coast of Brazil and in Samborombón, Argentina; with few exceptions of negative allometry and isometry, the LMC and the AW in these species grow in positively allometry both during the juvenile phase and in the adulthood (Tab. 2).

The levels of allometry recorded in the relative growth of LMC of $U$. uruguayensis $(b=1.72$ for juvenile males and $b=2.58$ for adults), were higher when compared with those of AW's ( $b=1.02$ for juvenile females and $b=1.73$ for adults) (Tab. 1). According to Hartnoll (1982), this difference occurs because the chelipeds are independent appendages and the abdomen a dependent executor. In other words, chelipeds are not functionally limited by the size of other organs, and within the mechanical limitations, the bigger the chelipeds, the more advantageous for males. On the other hand, the abdomen can only function together with the sternum, and any disproportionate increase in AW would reduce the efficiency of body movements and walking.

The allometry level of LMC recorded in the present study for $U$. uruguayensis $(\mathrm{b}=$ 2.58) was the highest among seven species of $U c a$ already studied in Brazil and Argentina (Tab. 2). The largest male of $U$. uruguayensis had $12.06 \mathrm{~mm}$ LMC and $8.33 \mathrm{~mm}$ CW, i.e., its LMC was slightly less than twice the CW. As for other species of the genus, the role of the giant cheliped in $U$. uruguayensis seems to be useful for combat, defense of territories and for waving during reproductive season (Crane, 1975).

Table 2. Allometry and levels of allometry (b) in the relative growth of the species of $U_{c}$ whose carapace width (CW) was considered as independent variable and the $\mathrm{CW}$ value in which the species attain its onset of morphological sexual maturity. (1) population of the Cavalo River, (2) population of Ubatumirim, SP (3) population of Itambuca, SP (4) population of Ubatuba, SP (5) population of Samborombón, Argentina, (0) isometry, (+) positive allometry, (-) negative allometry.

\begin{tabular}{|c|c|c|c|c|c|c|c|}
\hline \multirow{2}{*}{ Species } & \multirow{2}{*}{ References } & \multicolumn{2}{|c|}{ Males (CW $\times$ LMC) } & \multicolumn{2}{|c|}{ Females (CW x AW) } & \multicolumn{2}{|c|}{ Onset CW (mm) } \\
\hline & & Juvenile & Adult & Juvenile & Adult & Males & Females \\
\hline Uca burgersi (1) & Benetti and Negreiros-Fransozo (2004) & $1.66(+)$ & $2.01(+)$ & $1.29(0)$ & $1.64(+)$ & 8.80 & 6.50 \\
\hline Uca burgersi (2) & Benetti and Negreiros-Fransozo (2004) & $1.62(+)$ & $2.04(+)$ & $1.40(+)$ & $1.59(+)$ & 7.50 & 6.20 \\
\hline Uca leptodactyla & Masunari and Swiech-Ayoub (2003) & $2.19(+)$ & $1.24(0)$ & $1.30(+)$ & $1.07(0)$ & 8.35 & 7.40 \\
\hline Uca mordax & Masunari and Dissenha (2005) & $1.51(+)$ & $2.37(+)$ & $1.22(+)$ & $1.60(+)$ & 11.70 & 8.77 \\
\hline Uca rapax (2) & Castiglioni and Negreiros-Fransozo (2004) & $1.43(+)$ & $1.86(+)$ & $1.45(+)$ & $1.31(+)$ & 13.50 & 11.20 \\
\hline Uca rapax (3) & Castiglioni and Negreiros-Fransozo (2004) & $1.55(+)$ & $1.52(+)$ & $1.67(+)$ & $1.23(+)$ & 15.20 & 12.10 \\
\hline Uca rapax & Costa and Soares-Gomes (2008) & $1.98(+)$ & $0.84(-)$ & $1.44(+)$ & $1.31(+)$ & 12.07 & 6.78 \\
\hline Uca thayeri & Negreiros-Fransozo et al (2003) & $1.52(+)$ & $2.24(+)$ & $1.32(+)$ & $1.10(+)$ & 13.80 & 10.70 \\
\hline Uca maracoani & Masunari et al (2005) & $1.39(+)$ & $1.95(+)$ & $1.00(0)$ & $1.51(+)$ & 17.85 & 11.75 \\
\hline Uca uruguayensis (4) & Hirose et al (2013) & $1.74(+)$ & $1.68(+)$ & $1.22(0)$ & $1.12(+)$ & 7.10 & 5.90 \\
\hline Uca uruguayensis (5) & Hirose et al (2013) & $1.50(+)$ & $1.29(+)$ & $2.05(+)$ & $1.75(+)$ & 7.00 & 6.75 \\
\hline Uca uruguayensis & Present study & $1.72(+)$ & $2.58(+)$ & $1.02(+)$ & $1.73(+)$ & 4.14 & 3.52 \\
\hline
\end{tabular}


The level of allometry obtained for the growth of AW of adult females was also the highest among the seven species of $U_{c a}$ already studied in Brazil $(b=1.73)$, but a little smaller than Samborombón' females, Argentina (b $=1.75)($ Tab. 2). The high variation in the allometric level of AW $\mathrm{x}$ CW in females of $U c a$ (Tab. 2) certainly is related to the volume of the incubation chamber according to Hartnoll (1974): enlargement of pleon amongst females means the possibility to hold a higher number of eggs during this process.

The program REGRANS was appropriate to recognize the size in which $U$. uruguayensis attains adulthood (pubertal changes). The proximity of the value of the smallest ovigerous female $(=5.05 \mathrm{~mm} \mathrm{CW})$ to the inflection point in the dispersion graphs between CW and the AW (= $3.52 \mathrm{~mm} \mathrm{CW})$ supports this statement. According to Hartnoll (1982), even in case when the pubertal changes do not coincide with the gonad maturation, it will indicate the entrance for the instar, when the reproductive activity takes place. According to Haley (1973), other dimensions may also be indicative of the sexual maturity of decapods, such as the length of eyestalk that grows faster during the adult phase.

The lack of statistical differences in the handedness of males is in accordance with the studies of Yamaguchi (1977) and Yamaguchi and Henmi (2001), who also found a similar proportion between left and right-handed males in most species of $U c a$ whose handedness has been described. Uca species that do not present a balanced proportion of handedness constitute a minority: Uca tetragonon (Herbst, 1790), Uca vocans (Linnaeus, 1758), Uca vomeris (McNeill, 1920) and Uca dampieri (Crane, 1975) from Indo-Pacific coast have a strong right-handed dominance (Yamaguchi and Henmi, 2001). The dominance of lefthanded crabs is only recorded for Uca burgersi from the Barbuda Antilles, Western Atlantic coast, probably due to the reproductive isolation of this population (Gibbs, 1974; Williams and Heng, 1981). However the right-handedness in Uca arcuata from Kyushu, Japan, is not genetically determined, but it may be related to the loss of one of the chelipeds (Yamaguchi and Henmi, 2001).

ACKNOWLEDGMENTS - We are grateful to Prof. Dr. Luis Ernesto Arruda Bezerra from Federal Rural University of the Semi-Arid Region (UFERSA) for the confirmation of identification of Uca uruguayensis, to Prof. Dr. Luís Amilton Foerster from Federal University of Parana for reviewing the English revision, to M.Sc. Thaís Fernanda Moreto for her help in the field work and to Dr. André Trevisan for the assistance in the statistical analysis. All biological sampling of the present study complies with the current laws of Paraná State and Brazilian Federal Government, and it was conducted with the permission of SISBIO (Authorization No. 29567-1). This is Contribution No. 1892 of Zoology Department, Federal University of Paraná.

\section{REFERENCES}

Benetti, A.S. and Negreiros-Fransozo, M.L. 2004. Relative growth of Uca burgersi (Crustacea, Ocypodidae) from two mangroves in the southeastern Brazilian coast. Iheringia, Série Zoologia, 94(1): 6772.

Boschi, E.E. 2000. Species of decapod crustaceans and their distribution in the american marine zoogeographic provinces. Revista de Investigación y Desarrollo Pesquero, 13: 7-136.

Cardoso, F.C.R. and Negreiros-Fransozo, M.L. 2004. A comparison of the allometric growth in $U_{c a}$ leptodactyla (Crustacea: Brachyura: Ocypodidae) from two subtropical estuaries. Journal of Marine Biology Association of United Kingdom, 84: 733-735.

Castiglioni, D.S. and Negreiros-Fransozo, M.L. 2004. Comparative analysis of the relative growth of $U c a$ rapax (Smith) (Crustacea, Ocypodidae) from two mangroves in São Paulo, Brazil. Revista Brasileira de Zoologia, 21(1): 137-144.

Castiglioni, D.S.; Negreiros-Fransozo, M.L. and Mortari, R.C. 2006. Biologia populacional do caranguejo violinista Uca rapax (Smith, 1870) (Crustacea, Ocypodidae), proveniente de uma área de manguezal degradado em Paraty, RJ, Brasil. Atlântica, 28(2): 73-86.

Costa, T. and Soares-Gomes, A. 2008. Relative growth of the fiddler crab Uca rapax (Smith) (Crustacea: Decapoda: Ocypodidae) in a tropical lagoon (Itaipu), Southeast Brazil. Pan-American Journal of Aquatic Sciences 3(2): 94-100.

Crane, J. 1975. Fiddlers crabs of the world (Ocypodidade: Genus $U c a$ ). Princeton University, Princeton, 736p.

Gibbs, P.E. 1974. Notes on Uca burgersi from Barbuda, Leeward Island. Crustaceana, 27: 84-91.

Haley, S.R. 1973. On the use of morphometric data as a guide to reproductive maturity in the ghost crab, Ocypode ceratophthalmus (Pallas) (Brachyura, 
Ocypodidae). Pacific Science, 27(3): 350-362.

Hartnoll, R.G. 1974. Variation in growth patterns between some secondary sexual characters in crabs (Decapoda: Brachyura). Crustaceana, 27: 131-136.

Hartnoll, R.G. 1978. The determination of relative growth in Crustacea. Crustaceana, 34(3): 281-293.

Hartnoll, R.G. 1982. Growth. In: D.E. Bliss (ed.), The biology of Crustacea: embryology, morphology and ecology, Vol. 2. Academic Press, New York, 111196.

Hines, A.H. 1989. Geographic variation in size at maturity in brachyuran crabs. Bulletin of Marine Science, 45(2): 356-368.

Hirose, G.L.; Fransozo, V.; Tropea, C.; López-Greco, L.S. and Negreiros-Fransozo, M.L. 2013. Comparison of body size, relative growth and size at onset sexual maturity of Uca uruguayensis (Crustacea: Decapoda: Ocypodidae) from different latitudes in the southwestern Atlantic. Journal of the Marine Biological Association of the United Kingdom, 93(3): 781-788.

Masunari, S. and Dissenha, N. 2005. Alometria no crescimento de Uca mordax (Smith) (Crustacea, Decapoda, Ocypodidae) da Baía de Guaratuba, Paraná, Brasil. Revista Brasileira de Zoologia, 22(4): 984-990.

Masunari, S.; Dissenha, N. and Falcão, R.C. 2005. Crescimento relativo e destreza dos quelípodos em Uca maracoani (Crustacea, Decapoda, Ocypodidae) no Baixo Mirím, Baía de Guaratuba, Paraná, Brasil. Revista Brasileira de Zoologia, 22(4): 974-983.

Masunari, S. and Swiech-Ayoub, B.P. 2003. Crescimento relativo em Uca leptodactyla Rathbun (Crustacea, Decapoda, Ocypodidae). Revista Brasileira de Zoologia, 20(3): 487- 491.

Melo, G.A.S. 1996. Manual de identificação dos Brachyura (caranguejos e siris) do litoral brasileiro. Plêiade/Fapesp, São Paulo, 604p.

Miller, C. 1973. Growth in Uca, 1. Ontogeny of asymmetry in Uca pugilator (Bosc) (Decapoda, Ocypodidae). Crustaceana, 24: 119-131.

Negreiros-Fransozo, M.L.; Colpo, K.D. and Costa, T.M. 2003. Allometric growth in the fiddler crab Uca thayeri (Brachyuyra, Ocypodidae) from a subtropical mangrove. Crustaceana, 23(2): 273-279.

Nobili, G. 1901. Decapodi raccolti dal Dr. Filippo Silvestri nell'America meridionale. Bollettino dei Musei di Zoologia ed Anatomia comparata della $R$. Università di Torino 16(402): 1-16.

Pezzuto, P.R. 1993. REGRANS: a basic program for an extensive analysis of relative growth. Atlântica, 15: 93-105.

Rosenberg, M.S. 1997. Evolution of shape differences between the major and the minor chelipeds of Uca pugnax (Decapoda: Ocypodidae). Journal of Crustacean Biology, 17: 52-59.

Thurman II, C.L. 1984. Ecological notes on fiddler crabs of South Texas with special reference to $U_{c a}$ subcylindrica. Journal of Crustacean Biology, 4(4): 665-681.

Yamaguchi, T. 1977. Studies on the handedness of the fiddler crab Uca lactea. Biological Bulletin, 152: 424436.
Yamaguchi, T. 2001. Dimorphism of chelipeds in the fiddler crab, Uca arcuata. Crustaceana, 74(9): 913923.

Yamaguchi, T. and Henmi, Y. 2001. Studies on the differentiation of handedness in the fiddler crab, Uca arcuata. Crustaceana, 74(8): 735-747.

Williams, M.J. and Heng, P.K. 1981. Handedness in males of Uca vocans (Linnaeus, 1758) (Decapoda, Ocypodidae). Crustaceana, 40(2): 215-216.

Zar, J.H. 1999. Bioestatistical analysis, $4^{\mathrm{a}}$ ed. New Jersey, Prentice-Hall, 663p. 